\title{
Correction to: A thermo-mechanical model for SFRC beams or slabs at elevated temperatures
}

\author{
Peter Heek $\cdot$ Jasmin Tkocz $\cdot$ Peter Mark
}

Published online: 27 March 2019

(C) RILEM 2019

\section{Correction to: Materials and Structures (2018) 51:87 https://doi.org/10.1617/s11527-018-1218-8}

The article "A thermo-mechanical model for SFRC beams or slabs at elevated temperatures," written by Peter Heek. Jasmin Tkocz. Peter Mark, was originally published online without Open Access. After publication in volume 51, article ID 87 RILEM decided to grant the author to opt for open choice and to make the article an open-access publication. Therefore, the copyright of the article has been changed to (C) The Author(s) 2018, and the article is forthwith distributed under the terms of the Creative Commons Attribution
4.0 International License (http://creativecommons. org/licenses/by/4.0/), which permits use, duplication, adaptation, distribution and reproduction in any medium or format, as long as you give appropriate credit to the original author(s) and the source, provide a link to the Creative Commons license, and indicate if changes were made.

Publisher's Note Springer Nature remains neutral with regard to jurisdictional claims in published maps and institutional affiliations.
The original article can be found online at https://doi.org/10.1617/s11527-018-1218-8.

P. Heek · J. Tkocz $(\bowtie) \cdot$ P. Mark

Institute of Concrete Structures, Ruhr-University

Bochum, Universitätsstraße 150, 44780 Bochum,

Germany

e-mail: jasmin.tkocz@rub.de

P. Heek

e-mail: peter.heek@rub.de

P. Mark

e-mail: peter.mark@rub.de 